\title{
Miscellancea
}

\section{List of Competed Master Dissertation January 2010 to December 2011}

Adhikari, Somnath. Contribution of value added tax to national revenue collection: IRD Office Pokhara, MBS diss. 2066

Poudel, Sumitra. Problem and prospects of commercial banks in relation to deposit mobilization. MBS diss. 2066

Khadka, Kalpana. A study om market position of safal milk in Pokhara. MBS diss. 2066

Thapa, Amrit Babu. An analysis on budgeting practice of INF Nepal. MBS diss. 2066

Palikhe, Dipendra Man. An analysis on deposit mobilization of commercial banks. MBS diss. 2066

Sharma, Sandhya Devi. The study on analysis of capital structure and its effects on dividend of Unilever Nepal Ltd. MBS diss. 2066

Ghimire, Umesh, Financial performance analysis of leading commercial banks in Nepal. MBS diss. 2066

Pokhrel, Parbati. Comparative study of capital structure management between Himalayan \& Investment Bank. MBS diss. 2066

Kunwor, Bikram. Marketing \& strategies of bio-gas company in Nepal : National Bio-gas Company Ltd. MBS. diss 2067

Mainali, Uddhav K. Daily share price behavior of selected commercial banks in Nepal. MBS. diss. 2067

Devkota, Kamal C. A study on corporate tax contribution government revenue in Nepal. MBS biss. 2067

Poudel, Bhuwan Kumar. Risk and return on common stock investment of listed commercial banks. MBS diss. 2067

Adhikari, Hari Krishna. Profit planning and controlling in Nepalese commercial banks: Comparative study on Nepal Investment Bank \& Himalayan Bank Ltd. MBS diss. 2067 Banjara, Ramesh. A study on income tax collection from commercial banks in Nepal. MBS diss. 2067 Khatri, Suman. Financial performance of everest bank limited in the framework of return on equity. MBS diss. 2067

Paudel, Om Prasad. Financial performance analysis of Gandaki Multi Purpose Cooperative Society in framework of PEAR LS. MBS diss. 2067

Adhikari, Santosh. Inventory management of Nepal Oil Corporation Ltd. MBS diss.2067

Gurung, Pushpa. An opinion survey of loan disburment and collection policies of Machhapuchhre Bank Ltd. MBS diss. 2067

Ghimire, Thakur Prasad. Micro finance practies and its impact on women study of Chimek Bikash Bank Ltd. under Lakhnath municipality. MBS diss. 2067

Poudel, Bandana. An analysis on loan disbursement and repayment pattern of Agricultural Development Bank Ltd. in Nepal. MBS diss. 2067 
Pokhrel, Amrita. Comparative study on customer perception towards commercial banks. MBS diss. 2067

Sharma, Niraj. Projcet work: Capital structure management of commercial banks. MBS diss. 2067

Lamsal, Rita. Customer satisfaction in Nepalese commercial bank: Study on Everest Bank Ltd. Lazimpat Branch, Ktm. MBS diss. 2067

Parajuli, Rajendra. Financial analysis of Putali Bazar Municipality. MBS diss. 2067.

Pandey, Kabindra Raj. Comparative study of nin performing asset of Himalayan and Credit and Commercial Bank Ltd. MBS diss. 2067

Shrestha, Bipin kumar. Inventory management practices: Ratna Electrical Enterprise Pvt. Ptd. Pokhara. MBS diss. 2067

Shrestha, Prasanta. Portfolio analysis of Nepalese listed companies: Common stock of a group commercial banks listed in NEPSE. MBS diss. 2067

Paudel, Indra Prasad. Income tax in Nepal: Study of deductions and exemptions. MBS diss. 2067

Giri, Khim. Comparative analysis of profit planning practice in Himalayan Bank and Nepal Investment Bank Ltd. MBS diss. 2067

Subedi, Bhoj Raj. Marketing efficiency of commercial bank in Nepal. MBS diss. 2067

Subedi, Agni Prasad. Income tax on business income and its impact in revenue collection. MBS diss. 2067 Subedi, Raj Kumar. A study of non performing assets of Nepal Bank \& Rastriya Banijya Bank Ltd. MBS diss. 2067

Khatri, Kul Bahadur. Lending policy of Nabil Bank Ltd. MBS diss. 20677

Baral, Kul Raj. Hire purchase financing study of Pokhara Finance Ltd. MBS diss. 2067

Gurung, Buddha. Financial performance analysis of Nepal Credit and Commercial Bank Ltd. framework of CAMEL. MBS diss. 2067

Timilsina, Madhav Prasad.Structure \& analysis of internal debt finincing in Nepal. MBS diss. 2067 Bastola, Bishnu Prasad. The inerprise tax: Study of Pokhara Sub-municipality Corporation. MBS diss. 2067

Subedi, Guru Prasad. Employment tax reform in Nepal and it's contribution to the national revenue. MBS diss. 2067

Bastola, Nirmala. Behaviour of Nepal Stock Exchange Index. MBS diss. 2067

Parajuli, Bishwash. Comparative study on investment portfolio of Om Finance and Fewa Finance Ltd. MBS diss. 2067

Bhandari, Bishnu Prasad. Socio economic of microfinance for women: Study of Prabhabkari Women Development Saving and Loan Cooperative Ltd. MBS diss. 2067

Bhandari, Anil. Cost volume profit analysis of Bottlers Neopal Limited. MBS diss. 2067

Dhakal, Rishi Ram. Product planning and development under restructuring strategy in Rastriya Banijaya Bank. MBS diss. 2067

Bhandari, Bishwo Ram. Managerial budgeting in commercial bank: A case study of Nepal Investment Bank LTD. MBS diss. 2067 
Paudel, Asok. Distribution channel management system of tea production in Nepal: A case study of Shreehari Tea Industry Pvt. Ltd. MBS diss. 2067

Karki, Pratikshya. A study on profit planning and control of Nepal Insurance Company Ltd. MBS diss. 2067

Sarma, Bhagawati Kumari. Consumer behaviour with reference to decision making process of personal car purchase in Pokhara city. MBS diss. 2067

Adhikari, Laxman. A case study on financial performance of Nepalese Non life Insurance industry. MBS diss. 2067

Baniya, Shova. Impact of microfinance program for the upliftmemt of women: A case study of Kahun VDC in Kaski District. MBS diss. 2067

Tiwari, Ramesh Raj. A study on Small Farmer Co-operative Limited and it's effect: A case study of Begnas, Kaski. MBS diss. 2067

Shahi, Man Bdr. A comparative study on fund mobilization of Himalayan Bank LTD and Everest Bank Ltd. MBS diss. 2067

Subedi, Sandesh. Financial analysis of Sagarmatha Women Development Saving \& Credit Co-operative Ltd. in the framework of PEARLS. MBS diss. 2067

Shrestha, Bijaya. Financial performance analysis of Machhapuchchhre Bank Ltd. in the framework of CAMEL. MBS diss. 2067

Ghimire, Kabita Bhattarai. A case study on financial performance analysis of Fishtail Hospital \& Research Center Private Limited. MBS diss. 2067

Poudel, Deepak Raj. Risk and return analysis of common stock investment of financial company in Nepal.(with special reference of ten finance company). MBS diss. 2067

Jaishi, Rajendra Gautam. A case study of advertisement on over business of Everest Bank Limited. MBS diss. 2067

Dhuju,Nir Bikram. A comparative analysis of capital structure of commercial banks (with refference to Himalayan Bank and Bank of Kathmandu). MBS diss. 2067

Poudel, Bimal. A study on deposit collection and investment pattern of Bishal Co-operative Society Limited. MBS diss. 2067

K.C., Krishna Kumar. A study on investment portfolio of Fewa Finance Company Limited Pokhara. MBS diss. 2067

Thapa, Om Bdr. Impact of micro credit policy on women's empowerment: A case study of Jagatra Devi VDC Syangja. MBS diss. 2067

Tiwari, Shankar. Financial performance analysis of Pokhara Finance Company Limited in the framework of CAMEL. 2067

Parajuli, Prasha. A comparative study on financial performance of Indo-Nepal joint venture bank-Everest Bank Ltd. and Nepalese venture Bank-Kumari Bank Limited. MBS diss 2067

Yangchen, Miss Tsering. A comparative study on profit planning practices of Nepal Bank 122 
Limited and Nabil Bank Limited. MBS diss. 2067

Pathak, Nilkantha. Profit planning in general insurance: A case study of Everest Insurance Co. Ltd. MBS diss. 2067

Acharya, Madhu. Performance analysis of Shreejana Development Center Micro Finance Program in Kaski District. MBS diss. 2067

Ghimire, Keshab Sharma. Impact of trainin: A case study of skill for employment project (SEP) in Pokhara. MBS diss. 2067

Nepali, Puskar. Status of tourism and it's financial impact on hotel employee's lifestyle of Pokhara. MBS diss. 2067

Malla, Kiran. Financial analysis of Pokhara Sub-municipal Corporation. MBS diss, 2067

Dhakal, Pravin. The enterprise tax: A case study of Putali Bazar Municipal Corporation. MBS diss. 2067

Baral, Kishhor. A comparative analysis of financial performance of Nepal SBI Bank Ltd. in Nepal and Bank of Kathmandu Ltd. MBS diss. 2067

Pahari, Maheswor. Dividend policy and practice of joint venture bank Ltd in Nepal. MBS diss. 2067 Chapagain, Shalik Ram. Deposit and lending status of Himuchuli Bikas Bank Ltd Pokhara . MBS diss. 2067 Thapa, Mohan. Performance analysis of United Insurance Company Ltd. MBS diss. 2067 Jha, Manmohan. A study on impact on rate diverfication of internal and external service of Nepal Telecom. MBS diss. 2067

Gautam, Dharma Raj. A study on accounting information system in public bank of Nepal. MBS diss. 2067

Paudel, Umesh. Inventory management: A case study of Unilever Nepal Ltd. MBS diss. 2067

Aryal, Chandi Prasad . Financial performance analysis of Royal Co-operative society Ltd in the frame work of PEARLS. MBS diss. 2067

Khadka, Surya Bdr. Daily share price behaviour of commercial bank in Nepal. MBS diss. 2068

Baral, Nabin Kumar. A study on non performance assets \& profitability of Nepalese commercial banks. MBS diss. 2067

Khatri, Bimala. Risk and return analysis of private domestic commercial bank in Nepal. MBS diss. 2067

Gurung, Anila. A study on the status of NPA and loan portfolio of Business Development Bank Ltd. MBS diss. 2067

Dhungal, Anita. A comparative analisis of financial performance of Nepal SBI Bank and Macchhapuchhre Bank Ltd (in frame work of CAMEL). MBS diss. 2067

Adhikari, Santosh Bdr. Performance analysis of Premier Insurance Company in the frame work of IRDA. MBS diss. 2067

Gautam, Rajendra prasad. Micro finance and women enterprise development under village development programme: A case study of Nirmal Pokhari V.D.C Kaski. MBS diss. 2067 
Gurung, Prakash. A study hire purchase finance of Pokhara Finance Ltd (Bittya Sanstha). MBS diss. 2067 Sigdel, Shiva Nath. Decision making practices of Minibus Buying in Pokhara. MBS diss. 2067

Parajuli, Suman Keshab. A study on brand loyality towards consumer products in Pokhara. MBS diss. 2067

Kanu, Birendra Prasad. Mobilization of saving and credit of community development fund for women: A case study of Bhalam VDC of Kaski District of Nepal. MBS diss. 2067

Pun, Mina Kumari. Finincial sustainability of Pokhara Finance Company LTd. MBS diss. 2067

Bhandari, Bishnu. Micro credit of Bhutwal Municipality: A case study of PGBBL,Shankar Nagar Branch. MBS diss. 2067

Timilsina, Jeevan. Impact of micro finance programme of Chhimeki Bikash Bank on the study on rural women: A case study of Khairenitar Unit Office,Tanahun. MBS diss. 2068

Mahat, Hom Bdr. Financial performance analysis under the framework of PEARLS of Janasewa Saving and Credit Co-operative Ltd. Puranchour Kaski. MBS diss. 2068

Tripathi, Mukunda. Micro finance mobilization for poverty reducution through DDC: A case study of Kalika VDC Kaski. MBS diss. 2068

Shrestha, Lal Bdr. Impact of micro finance on women under Pashchimanchal Grameen Bikas Bank LTd in Dulegaunda VDC Tanahun. MBS diss. 2067

Subedi, Laxmi. Working capital management of furniture industries in Pokhara Sub-metro politan City. MBS diss. 2067

Lamsal, Rajendra. A study of profit and revenue planning of Nepal Telecom Ltd. MBS diss. 2067 Baral, Dil Bdr. Loan management of commercial bank: A case study of Kumari Bank.MBS diss. 2067 Gyawali, Mukunda. Role of micro finance in employment generation: A case study of micro finance programme under PGBB in Rupandehi District. MBS diss. 2067

Bhujel, Bharat. Corporate tax planning practices in the Nepalese business organization. with reference to Pokhara valley. MBS diss. 2068

Dhakal, Laxmi. Credit management: A comparative study of Himalayan Bank Ltd. and Nabil Bank Ltd. MBS diss. 2067

Poudel, Bimala. A study on capital structure management of selected commercial banks in Nepal. MBS diss. 2067

Gurung, Urika. Impact of advertising of the buying behaviour of the consumer in Pokhara. MBS diss. 2067 Munakarmi, Parag. Inventory management of manufacturing industries in Nepal: With reference to Himshree Foods Industries Pvt.Ltd. MBS diss. 2067/068

Adhikari, Raju. Role of tax revenue to strengthen the local government: A case study of Pokhara Sub-municipality Corporation. MBS diss. 2067/068

Aryal, Khuma Kanta. Impact of micro finance on women: A case study of National Education and Social Development Organization NESDO. MBS diss. 2067/068

Khanal, Pooja. Marketing of nettle fible(ALLO): A case study on Parche VDCof Kaski 124 


\section{District. MBS diss. 2068}

Rana, Sudip Bikram. A study on communication effectiveness of print advertising. MBS diss. 2068

Shrestha, Pradip. Impact of micro finance on women: A case study of Lekhnath Municipility Kaski. MBS diss. 2068

Baniya, Urmila. Effective of promotional programme with reference to United Telecom Ltd. MBS diss. 2068

Pahari, Ram Chandra. Financial performance and institutional sustainability in the frame work of PEARLS: A case study of Sarangkot Kaski. MBS diss. 2068

Dhakal, Laxman. Socio-economic impact of micro finance: A case study of Small Farmer Agriculture Co-operative Ltd Phedikhola. MBS diss. 2068

Bhat, Pooja Raj. Impact of micro finance on women: A case study of Lekhnath Municipality, Kaski,under Pashchimanchal Grameen Bikas Bank. MBS diss. 2068

Poudel, Srijana. A case study of women employment through micro finance programme under Nirdhan Utthan Bank Ltd Bharatpur,Chitwan. MBS diss. 2068

Dhungana, Dipak Joti. Producting offering and customer satisfaction: A case study in between Machhapuchhre Bank Ltd, chipledhunga branch and Nabil Bank Ltd New Road branch Pokhara. MBS diss. 2068

Pathak, Ishwora. Investment portfolio of finance companies: Comparative analysis of Annapurna Finance and Pokhara Finance. MBS diss. 2068

Gaudel, Goma. Non interest income effects on total income of commercial banks in Nepal. MBS diss. 2068 Pokharel, Suman. A study of business taxation in Nepal. MBS diss. 2068

Khatri, Prakash. Loan management of commercial Bank Ltd: A case study of Machhapuchhre Bank Ltd. MBS diss. 2068

Bohara, Yuba Raj. Personal finance knowledge and practice: An opinion survey with employed and SELF employed people in Pokhara. MBS diss. 2068

Tamrakar, Susmita. Problems and prospects of Nepalese stock market. MBS diss. 2068

Pun, Nabin. Performance appraisal of public campuses in Nepal: A comparative study of Janapriya Multiple Campus and Bal Kumari Collage. MBS diss. 2068

Chiluwal, Santosh. Impact of micro finance on women: A case study of Dhamilikuwa VDC. under Grammeen Bikas Bank Bhotewodar, Lamjung. MBS diss. 2067

Pokhrel, Deependra. Financial performance of Premier Insurance Company Ltd. MBS diss. 2067

Wagle, Dipak Raj. Financial performance analysis of Business Development Bank Ltd in the frame work of BESEL II. MBS diss. 2068

Basnet, Manju. Profitability and liquidity analysis of commercial banks: Nepal Investment and Machhapuchhre Bank Ltd. MBS diss. 2068

Adhikari, Dirgha Psd. Comparative financial analysis of commercial banks in the frame work of BASEL II.with reference to Nepal Investment Bank Ltd and Everest Bank Ltd. MBS diss. 2068 